\title{
Why Does Mary Weep? Emotion and Gender in Advent Lines 164-213 (Advent Lyric VII)
}

\author{
Alice Jorgensen ${ }^{1}$ (1)
}

Accepted: 21 May 2021 / Published online: 15 July 2021

(c) The Author(s) 2021

\begin{abstract}
This article re-reads Lyric VII of the poem Advent, the dialogue of Mary and Joseph. The division of speeches in this lyric has been debated, largely on grounds of the plausibility of the emotions that are apparently expressed by the characters, but there are in fact clear pragmatic grounds for seeing only three speeches in the poem. The emotional expression in these speeches should not be seen in terms of character psychology, but rather the establishment and negotiation of relational stances. In her first speech, Mary expresses bitter grief and draws attention to her weeping, which is because of the insults and gossip she is suffering; the accent on shame and reputation is a distinctive emphasis in the poet's treatment of the material. Her display of grief elicits Joseph's response and paves the way to resolution in Mary's final speech. Mary's tears are gendered, but not so much because tears are inherently feminine as because they are associated with petition and dependence, and reflect Mary's social subordination to her betrothed spouse. Lyric VII prompts its audience to a partial identification with Mary and reflection on their need for God and his mercy; such identification would work differently for female and male readers.
\end{abstract}

Keywords Old English poetry $\cdot$ Emotion $\cdot$ Gender $\cdot$ Sorrow $\cdot$ Shame $\cdot$ Advent

\section{Introduction}

The speech divisions in Advent Lyric VII, which comprises lines 164-213 of the Exeter Book poem Advent (also known as Christ I or The Advent Lyrics), have stimulated repeated discussion. Editors and critics agree that lines 197-213 are in the voice of Mary, since they are preceded by an unambiguous speech introduction ("Pa seo fæmne onwrah / ryhtgeryno, ond pus reordade", "then the woman revealed the true mystery, and spoke thus", 195b-96). The disagreement is in how to treat the earlier part of the lyric, and there are two main approaches, the "unifying" and

Alice Jorgensen

jorgena@tcd.ie

1 Trinity College Dublin, the University of Dublin, Dublin, Ireland 
"fragmenting" interpretations (Harlow 1985: 101; Clayton 1990: 191). "Unifiers", such as Cosijn (1898), Burlin (1968), Harlow (1985), and Clayton (1990, 2013), take the two occurrences of "eala" in the lyric to mark speech openings, and read one speech by Mary beginning at 164 ("Eala Ioseph min...") and a reply from Joseph beginning at $175 b$ ("Eala fæmne geong...”). However, many critics and the majority of editors have found the division of 164-195a into only two parts improbable. In particular, they have boggled at its implications for the characters' emotions, especially the extended expression of grief it assigns to Mary. Certainly the ultimate biblical source, Matthew 1:18-25, focuses on Joseph's distress at learning of Mary's pregnancy (Pope 1985: 904), and so does the antiphon (“O Joseph") identified by Hill (1977) as the immediate source; but the treatment of the antiphon is expansively creative in any case and critics seem largely influenced by their sense, explicit or not, of what is plausible for the characters. For Anne Klinck (1979: 602), for example, "any kind of mental turmoil is out of keeping with [Mary's] especial purity and grace". ${ }^{1}$ Such considerations have led to a variety of arrangements, including Thorpe (1842), Cook (1900), Krapp and Dobbie (1936), Campbell (1959), and Muir (2000), in which the earlier section of the poem is subdivided into four or more short speeches in order to assign most or all of the lines expressing anxiety or grief to Joseph. $^{2}$

The present discussion starts from the position that the "unifying" approach is correct, and that the "fragmenting" approach suffers from the problem of deriving structure from interpretation (a fault criticized but not avoided by Foley 1975; see Anderson 1979). In the absence of any way of identifying speech divisions through punctuation in the manuscript, it is difficult to see how a reader would navigate the changes of speaker except through conventional markers such as "Eala", which consistently signals speech openings elsewhere in Advent; it is the first word of all eleven of the lyrics in the sequence for which a beginning survives (the text is acephalous). Elise Louviot's recent work on direct speech in Old English poetry has reinforced the sense that poets prefer "clearly delineated units" (2016: 43). ${ }^{3}$ The task, therefore, is to explain the apparently problematic emotions of Joseph and Mary within the three speeches marked by clear pragmatic signals in the text. Mary Clayton (1990: 193) points out that Mary's distress at the start is sufficiently explained by Joseph's intention to leave her, commenting "The reading advocated by Cosijn and Burlin does...make sense...psychologically (though it may be doubted whether that was a major interest of the poet)" (1990: 195). It is possible to build on this common-sense approach: the question of what it means to "make sense psychologically" needs to be re-examined in the

\footnotetext{
1 Other appeals to psychology against the "unifying" arrangement include Pope (1985: 903): "a close look at the psychological implications compels me to reject it"; Hill (1977: 14): "one can hardly imagine Mary worrying about what the neighbours would think after the Annunciation".

${ }^{2}$ Harlow (1985) divides the lyric into three speeches but argues that Joseph and Mary sometimes quote each other's words. Some fragmenting arrangements do allow a measure of grief to Mary, for example Isaacs (1966) and Anderson (1971).

${ }^{3}$ Louviot (2016: 24-35) also comments on the tendency for speeches to be long, and for dialogues to include only two or three turns.
} 
context of both the nature of Advent as liturgical verse and scholarship on emotions and mentality. Though this section of the poem has a dramatic character, it needs to be interpreted as part of a prayerful and meditative sequence in which emotion discourse, including expressions of sorrow, joy, and wonder, works to relate the poem's audience to the great mystery of the Incarnation.

The present article therefore re-reads Advent Lyric VII, making the following claims:

1. Emotion language functions in Advent primarily to define, animate and negotiate situations and relationships, rather than to give a detailed sense of personal psychology.

2. Mary's weeping helps both to dramatize and to negotiate a situation which is imagined predominantly in terms of social disgrace and shame-a distinctive emphasis in how the "Doubting of Mary" episode is developed by the poet.

3. The opening of Lyric VII aligns Mary and her sorrow with a position recurrently occupied in the sequence by the audience, so that while this lyric is the only one in Advent to be wholly dramatic in character, it nonetheless involves the audience in the movement from earthly vulnerability to heavenly glory through the person of Mary.

The presentation of Mary in Advent has been of interest to scholars of gender (Chance 1986; Lees 1997; Farina 2001; Dockray-Miller 2002; Donavin 2012), and this re-reading of emotion in Lyric VII has implications both for understanding the gendered position of Mary and for considering how sorrow and tears are gendered. This aspect of the discussion will emerge particularly in the final section of the article.

\section{Reading Emotion in Advent (Christ I/The Advent Lyrics)}

The expressions of emotion in Advent Lyric VII need to be understood in the context of Advent as a whole. Before elaborating this claim further, however, it is necessary to defend the unity of the text. There is some force in Anya Adair's arguments that the lyrics are not all by the same author; particularly persuasive is her observation that they handle metaphor and structure in different ways and with varying skill (2011: 832-43). ${ }^{4}$ Nonetheless, they are presented together, in five rather than twelve blocks of writing, in the Exeter Book, and are closely similar in approach-enormously more similar to each other than to Christ II (Ascension), which follows (Hill 1986); even if the lyrics were composed by several people, it seems likely those people were working together. While it would be possible to envisage a different

\footnotetext{
${ }^{4}$ Campbell (1959: 9-11) also argues that the lyrics should not be regarded as one work, on the grounds that there is (in his view) no continuous thematic or emotional thread connecting them, but I find Adair's arguments, which are based on a close consideration of poetic technique, more persuasive than Campbell's and more pertinent to the question of authorship.
} 
ordering of the elements, the sequence as a whole shows a progression from expectancy to joy, from Advent to Christmas (Rankin 1985: 317). I therefore continue to think it legitimate to interpret Advent as one (multi-authored) work.

The lyrics that make up Advent are based for the most part on the great "O" antiphons sung at the offices of Lauds and Vespers during Advent, though they reflect a collection of antiphons more extensive than that in any surviving manuscript of the period (Cook 1900: 71-73; Rankin 1985: 327-33). Each lyric, like the antiphons, begins with an apostrophe to Christ, Jerusalem, Mary, or the Holy Trinity, and continues with contemplation of the mysteries of the incarnation and prayers to Christ to come swiftly and save his people. Although there are passages-such as Lyric VII-which present the speech of biblical persons or the faithful of the past, and there are some sections that offer exposition or narrative framing, the lyrics recurrently speak not to but with and for their audience; readers or hearers of this poetic sequence are invited to join in words of petition and praise. While it seems in many ways suited for private devotional reading, it speaks in the plural not the singular and evokes the communal voice that prays in the monastic office (just as it seems likely itself to be the creative product of a community rather than an individual). Christopher A. Jones (2013: 444 and 448) has pointed out how Advent belongs to a "spreading middle ground" between the liturgical and the devotional. Within this middle ground, Advent draws on the resources of Old English poetic diction to elaborate the source antiphons in a way that both aids meditation, deepening understanding, and enhances how the poem scripts its users' own expressions of need, wonder and praise towards God.

As Britt Mize (2013) has shown, a characteristic feature of traditional Old English poetic diction is the language of subjectivity, which includes the language of emotion. Looking at instances where poets are adapting Latin source material, such as Genesis A, Mize observes that they add frequent allusions to the emotions, thoughts and mental states of characters; such "subjectivizing moments" are a standard part of how Old English poetry conveys narrative situations. According to Mize (2013: 19), "the continual reference to qualities and states of mind in classical Old English verse works less to create distinctive fictional persons than to evoke a system of ethical positions and relationships, even when such a system is not fully articulated within a given text". In Advent, the use of the language of subjectivity, and specifically of emotion, to elaborate an "ethical position" is evident, for example, in the extended speech of the captives in hell in Lyric VI, which begins as follows:

$\mathrm{Nu}$ pu sylfa cum,

heofones heah-cyning. Bring us hælo lif, werigum wite-peowum, wope forcymenum, bitrum bryne-tearum. Is seo bot gelong eal æt pe anum for ofer-pearfum; hæftas hyge-geomre hider geseces. (149b-54) 
Now come in person, high king of heaven. Bring the life of salvation to us weary slaves in torment, overcome by weeping, by bitter scalding tears. The remedy for those in dire need rests on you alone; you will come hither to seek sorrowful-minded captives. ${ }^{5}$

References to weeping, tears, weariness and sorrow of mind underscore the profound need of these captives, and of fallen humanity more generally, for the Saviour, and thus help to unfold the meaning of the Incarnation. The speech does not in any way create distinctive dramatic personalities for the speakers, but it establishes their relationship to Christ through an emotional stance, and in the context of the lyric sequence it also underscores a relationship to the Christians of the present, since similar pleas are put into the mouths of the praying audience. In Lyric II, based on the antiphon "O key of David", the audience is given a prayer to Christ, who holds the keys, to deliver us from the prison of our fallen state:

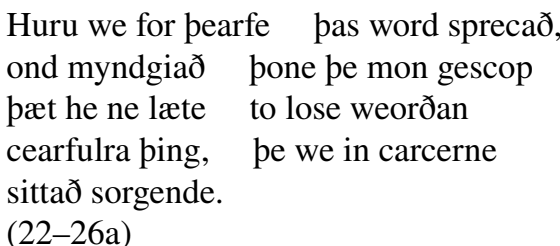

Indeed, we speak these words out of need, and entreat him who created man to be mindful not to let the affairs of us troubled ones, who sit in prison sorrowing, to come to ruin. ${ }^{6}$

The "system of ethical positions and relationships" in Advent links the situation of those longing for Christ's first coming to those awaiting his second and reveals their similar dependence on Christ, rendered vivid and urgent through references to emotion. In the examples given, the emotion discourse is that of sorrow, suffering, and tears and appeals to the common Old English poetic theme of this life as a spiritual exile (Greenfield 1953); but elsewhere Advent has much to say about wonder and joy. The language of emotion deepens the audience's understanding of the contrast of fallenness and salvation and of the power of God's mercy.

Emotion discourse, then, expounds situations and relationships, and in the context of Advent aids deeper comprehension of the meaning of Christ's coming. Moreover, one can draw on the framework of "situated emotions" outlined by the philosophers

\footnotetext{
5 Quotations from Advent are from Clayton (2013), since my approach to Lyric VII builds on her interpretation. Clayton presents Advent as one poem, but I follow Muir (2000) in identifying the following twelve component lyrics: Lyric I is lines 1-17; II 18-49; III 50-70; IV 71-103; V 104-29; VI 130-63; VII 164-213; VIII 214-74; IX 275-347; X 348-77; XI 378-415; XII 416-39. Translations from Old English are my own, but I acknowledge the strong influence of Clayton's renderings.

6 The first folio of the MS is damaged; lines 23 and 24 present some difficulties and are presented as fragmentary by Krapp and Dobbie (1936: 5). Clayton (2013) and Muir (2000) agree in the emendations presented here.
} 
Paul Griffiths and Andrea Scarantino to argue that the language of emotion also actively negotiates the relationships it establishes. For Griffiths and Scarantino (2009: 437), emotions need to be understood as modes of interaction within a social environment: "an emotion is often an act of relationship reconfiguration brought about by delivering a social signal". To return to the prayer of the sorrowing in Lyric II, this is not simply a description of the situation of Christians in need of their Saviour: it is an active expression of longing for Christ, a prayer that Christians believe He will answer with mercy. Prayer seeks a response; indeed, in an insightful recent study, Stephanie Clark (2018) has theorized prayer in early medieval England as a species of gift exchange, in which a bond of reciprocity is established with God. The expression of sorrow constitutes a gesture of humility, an acknowledgement of one's sinful state, and a plea for pity, and it does not merely show but build and enact a relationship of dependency on God.

The next section of the present discussion offers a close reading of Lyric VII in light of these ideas about establishing and negotiating relationships. It explores how the emotion language in Mary's and Joseph's speeches vivifies their situation but also articulates stances towards each other, moving them forward towards the resolution offered in Mary's account of the angel's message. In this reading the accent is not on truth to supposed character, but the functionality of emotion expression in a social context, though it must be acknowledged that the social interaction itself is depicted in a highly stylised way. The final section of the article turns to how the dramatic vignette contributes to the audience's negotiation of relationship with the holy figures depicted in the lyric and, more broadly, with Christ as the Saviour to come.

\section{The Emotions of Mary and Joseph in Lyric VII}

Mary's first speech expounds her position as the calumniated betrothed of an older man. The language of sorrow both expresses, in the conventionally subjectivizing manner of Old English poetry, the difficulty of her situation, so that the audience will more vividly understand it, and negotiates that situation: her display of grief elicits Joseph's response in which he describes his own distress and confusion over what to do. This confusion and distress are answered in Mary's explanation that she has been chosen to bear God's son, and her admonition "nu pu ealle forlæt / sare sorg-ceare" ("now forsake all your bitter sorrow and anxiety", 208b-9a).

Throughout, the poet draws out the public dimension of gossip and social shaming in the episode. The antiphon "O Joseph" from Alcuin's De laude Dei, identified by Thomas D. Hill (1977) as the main source, asks how Joseph could have believed ill of Mary, the holy maiden:

O, Joseph, quomodo credidisti quod antea expavisti? Quid enim? In ea natum est de Spiritu Sancto quem Gabrihel annuncians Christum esse venturum.

O Joseph, why did you believe what before you feared? Why indeed? In her is born by the Holy Spirit the one whom Gabriel announces will come as the Christ. 
As C.G. Harlow (1985: 105) puts it, "the poem takes the place of the antiphon, rather than deriving from it". Of a range of additional sources for the Doubting of Mary which may have been known to the poet, the one that seems most obviously to have been drawn on, especially for Joseph's speech, is Pseudo-Augustine Sermo 195 (Clayton 1990: 187-90); however, the emphasis on reputation, shame, and the pressure of community reaction is not paralleled in Sermo 195. It seems that the poet, probably aware of multiple versions of the story, chose to elaborate a dimension particularly relevant to an audience brought up in a shame culture. ${ }^{7}$ Neil D. Isaacs says the reference at lines 183-85a to refuting hostile talk cannot refer to external gossip because "there can have been no external rumors, or Joseph's whole problem would be nonexistent" (1966: 165). This is not the case: there is a difference between gossip and formal accusation, and Lyric VII imagines a situation in which damaging rumours are rife but Joseph still has a choice in how to tackle the demands of the law. The stress on rumour and reputation in Lyric VII in itself highlights the importance of social meaning rather than individual psychology in the lyric.

Mary's opening lines swiftly indicate the dramatic situation: Joseph has learned of Mary's pregnancy and is wondering whether to end the relationship.

Eala Ioseph min, Iacobes bearn,

mæg Dauides mæran cyninges,

na [MS: nu] pu freode scealt fæste gedælan,

alætan lufan mine.

(164-67a)

O my Joseph, son of Jacob, kinsman of David the famous king, you must not

[MS: now you must] divide our firm friendship, renounce my love.

It is hard to be certain of the tone here. Clayton (2013) adopts the emendation of MS "nu" to "na" proposed by Pope (1985), making Mary tell Joseph not to leave her; this could be interpreted as a plea or as an instruction. ${ }^{8}$ However, the opening lines also include an elaborate address to Joseph that suggests Mary is showing him great respect; she calls attention not only to her own relationship to him but his illustrious descent from King David. This careful address makes sense if Mary is asking Joseph to do something face-threatening: to stay with her despite the difficulty that they are in. ${ }^{9}$ At the same time the reference to Joseph's ancestry-which

\footnotetext{
7 The idea that pre-Conquest England was a shame culture is widespread; one essay that explicitly defines this idea and applies it to Old English texts is Bremmer (2014). Baker (2013) focuses on honour rather than shame (in Beowulf) but is detailed and illuminating. See also Wilcox (2003); Cowen (2004); Jorgensen (2013); Birnbaum (2015).

8 An alternative tradition, keeping the MS “nu", follows Dietrich (1853: 197) in reading these lines as a question ("must you now divide our friendship?"), but the lack of syntactic inversion is not widely paralleled in questions in Old English (Pope 1985: 905-6). Otherwise it would seem necessary to finesse the translation of "scealt": "now you are to divide our friendship"; there are certainly indications that in some instances of OE sculan "the obligation sense [was] shading into a future meaning" (Lowrey 2012: 4.2.2). Pope's emendation seems the most satisfactory solution, nonetheless.

9 Compare Louviot's discussion (2016: 153-56) of Beowulf's elaborate address to Hrothgar when asking to fight Grendel, whom Hrothgar and his men have been unable to defeat.
} 
Mary shares-conveys how high the stakes are. According to Georgina Donavin, their royal descent shows the "inappropriateness of any stigma against them" (2012: 33), but the implication is not that great honour cannot be impugned but that its loss is extremely serious. Mary goes on to make the threat to honour explicit:

\section{Ic lungre eam}

deope gedrefed, dome bereafod,

forðon ic worn for pe worda hæbbe

sidra sorga ond sar-cwida,

hearmes gehyred, ond me hosp sprecað,

torn-worda fela. Ic tearas sceal

geotan geomor-mod.

(167b-72a)

I am at once deeply troubled, bereft of reputation, because I have heard on your account a multitude of harmful words, ample sorrows and insults, many painful speeches. With a sad heart I must pour out tears.

Judith Garde (1990: 127) interprets "dome bereafod" as "having absolutely no choice in the matter" and Donavin (2012: 34) translates "hosp" as "blasphemy", but both of these terms are better seen as part of a picture of social shaming and scurrilous gossip which is also alluded to later by Joseph (183-85b). Dom can mean something like "free choice" in the phrases sylfes dom and agen dom, but here is best translated "glory, good reputation"; ${ }^{10}$ hosp is a common word for shame, insult or mockery, found largely in prose, but poetic instances include the damaging talk visited on the "widgongel wif" ("wide-roaming woman") in Maxims I ("hæleð hy hospe mæneð", "men speak of her insultingly", 65a). ${ }^{11}$ The compounds "sar-cwida" and "torn-worda" (both genitive plural) fuse the ideas of other people's speech and the pain it causes; sar can convey both emotional and physical pain, while torn is a distinctive emotion term that lies at the crossing point of anger and grief, and that descends from the Proto-Indo-European root *der- "skin, flay, split" or "break, burst" (Izdebska 2015: 64-72). Both words thus characterise being the victim of hostile, shaming gossip as a matter of intense distress. The insults are directed against Mary ("me sprecað") but she suffers them for or on account of Joseph ("for pe"). This may be because all would assume Joseph was the father of her child (Garde 1990: 123); even if not, it registers that the shameful situation affects them both.

Mary's reaction to social shame consists of both internal grief ("geomor-mod") and the external gesture of weeping ("tearas"). Old English poetry mentions such exterior signs of emotion much less often than it refers to emotions within the breast or the mod (Cooper 2011: 179). Mary's description of her situation, her sorrow, and

\footnotetext{
10 The Dictionary of Old English, s.v. dōm, cites Advent 168b under sense 11f "to lose glory; domes lease "inglorious". For sylfes dom and agen dom see sense 7.

11 Cited from Krapp and Dobbie (1936). In Muir (2000) this is line 64a (reading "hi” not "hy").
} 
her weeping thus has a demonstrative, expressive character: it both describes and constitutes a performance of grief. Nonetheless it concludes with a declaration of faith that the sorrow is only temporary and God will bring comfort:

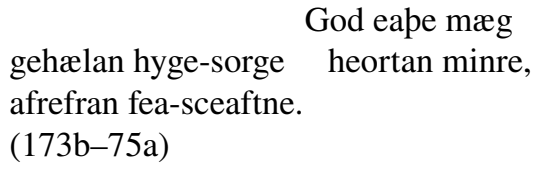

God can easily heal the inner sorrow of my heart, and comfort a wretched man.

Though it has been suggested masculine accusative "fea-sceaftne" should be emended to feminine "fea-sceafte" ("God can easily heal the inner sorrow of my heart, comfort a wretched woman"; see Clayton 1990: 191), the manuscript reading reinforces a sense that Mary is speaking about a sorrowful situation she shares with Joseph, and looking forward to his consolation as well as her own.

The apparent psychological contradiction between Mary's bitter grief and her confident expression of faith-which Harlow tried to solve by arguing Mary was quoting Joseph's complaints back to him (Harlow 1985: 103 and 108-12) - is a nonproblem. The conjunction of sorrow and faith is key to Mary's position at the Crucifixion, too (Donavin 2012: 33), and a trajectory from suffering, through faith, to joy governs many of the Psalms (Toswell 2010). Nonetheless, the emotional character of Mary's first speech in Lyric VII makes more sense if it is read, on the one hand, as a way of defining and dramatizing her position for the benefit of the poem's audience and, on the other, as active negotiation of her relationship with Joseph. For the audience, the emphasis on sorrow, pain and tears positions Mary as one who is vulnerable and makes vivid the ideas of hostile gossip and loss of reputation. It is common in Old English poetry to characterize changing dramatic situations in terms of contrasts between joy and sorrow, and the situation at the start of Lyric VII is one of woe. In the context of her relationship with Joseph, Mary's display of grief shows her sense of the seriousness of the shame that threatens both of them. Since sorrow is strongly associated in Advent with humility, dependency and petition, Mary's grief also shows her performing her gendered role as the female betrothed, subordinate to the man and dependent on him, and making a request that she wishes him to grant.

Grief makes demands, and so does shame. In the Norse sagas are numerous examples of whetting scenes in which women or other dependent figures goad men to vengeance by shaming them; the men often respond with resentment, but effective goading produces action (Miller 1990: 211-14; Miller 1983: 181). Old English literature does not offer close parallels, but in Beowulf acts of vengeance are strongly associated with grief (Sebo 2015), and this is often a grief expressed by a non-combatant that prompts violent action by another. Hrothgar's speech of mourning for Æschere elicits Beowulf's journey to the mere to kill Grendel's mother, and the elderly warrior who goads one of Ingeld's warriors to vengeance does so 
"geomormod" ("sorrowful at heart", Beowulf 2044a). If Joseph's question "hwæt bemurnest pu?" has an irritable tone, this is because Mary's display of grief and her focus on insult ("hosp") create an uncomfortable pressure on him in the manner of whetting. From this perspective, there is even a potential double meaning in Mary's statement that God can easily bring comfort. Hrothgar says something similar in his first conversation with Beowulf. Hrothgar describes the sorrows and shame ("hȳnðo", 475a) Grendel has inflicted on him and comments that "God eape mæg pone dolsceaðan dǣda getwæ̈fan" ("God can easily hinder the deeds of the wild ravager", $478 \mathrm{~b}-79){ }^{12}$ he then says that many men have previously vowed to defeat Grendel and failed, before bidding Beowulf to think of glory. The reference to what God can easily grant is obliquely part of the challenge to Beowulf to play his heroic part, seek the success that God is able to grant, and do better than the others. Mary is not challenging Joseph to dispel shame through vengeance or violence, but to endure it, to stand by her in her sorrow, and to have faith that God will comfort them. Nonetheless, her speech is provocative and goads Joseph to respond.

Joseph's opening words expose the tensions within the human situation that can only be resolved by the full revelation of Mary's virgin conception through the Holy Spirit:

Eala fæmne geong,

mægð Maria, hwæt bemurnest ðu, cleopast cearigende? Ne ic culpan in pe, incan ænigne, æfre onfunde, womma geworhtra, ond pu pa word spricest swa pu sylfa sie synna gehwylcre firena gefylled. Ic to fela hæbbe pæs byrdscypes bealwa onfongen! $(175 b-82)$

O young woman, maiden Mary, what do you mourn, what do you cry out over, sorrowing? I never found a fault in you, any suspicion of defilements committed, and you speak as though you were filled with every crime and sin. I have experienced too much suffering because of this pregnancy.

The question "hwæt bemurnest pu?" is particularly rich in implication. In terms of relationship negotiation, it is a rebuke, parallel to Mary's question to the children of Salem in Lyric IV where she repels their prurient curiosity over the virgin birth, saying "Hwæt is peos wundrung pe ge wafiað?" ("What is this astonishment by which you are amazed?", 89)—a question both Campbell (1959: 21) and Anderson (1971: 231) label "reproving". When Joseph asks Mary what she is crying about, he asserts his position of authority within their relationship; addressing her as "fæmne geong" ("young woman", 175b) also underscores his superior status. His question resists the demand made by her display of grief and the stress on social shaming in her speech

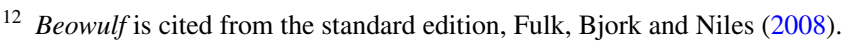


which, as noted above, implicates him. Moreover, although Joseph has never had any cause before to suspect her virtue, the "hosp" and loss of "dom" that Mary draws attention to are, as far he knows, the consequences of her adultery. For the audience, already aware through their knowledge of Christian teaching that Mary is not guilty of sin, the question "hwæt bemurnest pu?" exposes the gap between the exterior aspect of shame, the insults and cruel talk that Mary is already suffering, and moral shame before God. Mary's weeping relates to the former, not the latter; but Joseph cannot know this. According to Judith Garde, Joseph himself is able to testify to Mary's innocence, and his meaning can be summarized as: "I don't know what you are crying about, because, in spite of everything you are saying, I know that you are without fault" (1990: 127). This is surely wrong; Joseph's words convey his confusion and the difficulty of understanding how Mary could be without blame. However, "I don't know what you are crying about" is arguably one layer of meaning in "hwæt bemurnest pu?". At lines 181b-82 Joseph shifts the focus to his own sufferings.

The second part of his speech expands on the picture of social shame given by Mary and elaborates his dilemma over what to do:

Hu mæg ic ladigan lapan spræce,

oppe ondsware ænige findan

wrapum towipere? Is pæt wide cuð

pæt ic of pam torhtan temple Dryhtnes

onfeng freolice fæmnan clæne,

womma lease, ond nu gehwyrfed is

purh nathwylces. Me nawper deag,

secge ne swige. Gif ic soð sprece,

ponne sceal Dauides dohtor sweltan,

stanum astyrfed. Gen strengre is

pæt ic morpor hele; scyle man-swara,

lap leoda gehwam lifgan sippan,

fracoð in folcum.

(184-95a)

How can I counter hateful speech, or find any answer in response to hostile people? It is widely known that I willingly received a pure woman, without defilement, from the glorious temple of the lord, and now that is changed through I know not what. Neither is good for me, speak or be silent. If I tell the truth, then David's daughter must die, killed with stones. Still worse is it that I conceal crime; the perjurer must afterwards live hateful to every nation, despised among the people.

Again, there is stress on the public dimension of the situation and the scrutiny of other people: what was "widely known" about Mary and Joseph before the pregnancy, the opprobrium and rejection visited on one who swears falsely (oaths being a lynchpin of early medieval social bonds and legal procedures), and the identity of Mary as the descendent of David, with family honour hanging on her fate. The reference to telling the truth presumably means testifying that Joseph himself is not the father of Mary's child, leaving her to be stoned as an adulteress-which would still 
be dishonouring for Joseph, quite apart from his love for her. Joseph's inability to do good either by talking or keeping silent echoes the connection of words and pain in Mary's first speech. There is much less explicit emotion language in Joseph's speech than in Mary's, but his account of the situation is implicitly coloured by her account of distress, while focusing on the difficulty of deciding how to act.

Mary's concluding speech resolves Joseph's questions and, contrasting with her earlier performance of grief, establishes a very different position for her at the end of the lyric. The insertion of the speech introduction at $195 \mathrm{~b}-6$ provides a formal break that registers the change of tone. Now Mary speaks with the full authority of the one who has received the angel's message. Her declaration "soð ic secge" ("I tell the truth", 197a) echoes Joseph's "gif ic soð sprece" ("if I tell the truth", 159b), but unlike him she actually knows the truth, for Gabriel has "sægde soðlice" ("spoken truly", 203a) to her. Similarly, his reference to receiving a pure maiden from the "torhtan temple" ("glorious temple", 186) becomes her declaration that "nu ic his tempel eam / gefremed butan facne" ("now I am made his temple without fault", 206b-7a). In the course of many such verbal echoes linking this speech to the first two (Foley 1975: 115), the language of sorrow and its causes is reworked and resolved. Mary's earlier statement that God can easily "afrefran fea-sceaftne" ("comfort a sorrowful man", 175a) is recalled in the revelation that "in me frofre Gæst / geeardode" ("in me the spirit of comfort has dwelt", 207b-8a). Now, so far from lamenting her own "sidra sorga" ("ample sorrows", 170a) or being asked why she "cleopast cearigende" ("cry out sorrowing", 177a), she tells Joseph to abandon his "sorg-ceare" ("sorrow and anxiety", 209b). Instead of expressing the pain caused by insulting words, Mary solves Joseph's dilemma of speech or silence by telling him what to say:

Saga ecne ponc

mærum meotodes Sunu pæt ic his modor gewearð,

fæmne forð sepeah, ond pu fæder cweden

woruld-cund bi wene.

(209b-12a)

Say eternal thanks to the glorious Son of God that I have become his mother, though still a virgin, and you will be called his father in the opinion of the world.

Even the talk of the community is now transformed into a source of honour, since Joseph will be regarded as the father of Christ. The sense of both language and emotion now entirely under control, with demonstrative grief replaced by serene knowledge and authority, constitutes a sharp reversal of the situation set up in the first two speeches of the lyric, but it ties together all the threads and questions introduced in them. For the audience, it articulates the double identity of Mary, as both humble maiden and Mother of the Saviour, betrothed of Joseph and chosen of God.

To summarize the character and functions of emotion-talk in Lyric VII as they have been examined so far: Mary's first speech constitutes a demonstrative expression of grief which does not so much anatomise her psychological processes as animate for the audience the shame and loss of reputation shared by both characters. It also negotiates her relationship with Joseph, provoking his response. Speaking about 
emotion is bound up with authority, and Mary's speech performs her subordination to her betrothed husband; Joseph's question "Hwæt bemurnest pu?" performs his dominance, while also responding, in a manner both prickly and bemused, to the implicit demand made by her grief. Joseph's speech sets out the dilemma he faces and his own distress. Mary's final speech takes over the position of authority, offering instruction and comfort, and reveals the divine reality that resolves the painful human drama of the first two speeches. Throughout, the poet emphasises the dimensions of honour and shame, offering a distinctive interpretation of the "Doubting of Mary" episode calculated to appeal to an early medieval English audience.

This close reading of the emotions of the characters in Lyric VII has implications for gender. The assignment of the most explicit display of sorrow to Mary rather than to Joseph might be taken to support arguments that sorrow and tears are feminizing in Old English poetry, and are associated with passivity (Hill 1990; Dockray-Miller 1998; Cooper 2011); ${ }^{13}$ Mary laments and weeps, but Joseph considers what to do. Such arguments have been effectively questioned, however, from various angles: poems like Beowulf contain no shortage of sad men (Norris 2019); weeping may be compatible with social power (Mills 2015); sorrowing can be read as an active strategy (Neidorf 2017). The present article suggests that Mary's sorrow is both active and gendered. Her performative sorrow asserts her relationship with Joseph, highlights the shame that threatens them both, and challenges him to respond. She does this in a way that emphasises her dependence on him and deference to him; her tears do indeed signal vulnerability and need. At the same time, it is clear that the shame is as much his as hers, and so is the distress; what is asymmetrical is the capacity to engage with the law. When, in her final speech, the hierarchy of marriage is reversed and Mary becomes the voice of serene authority, she remains insistently gendered as a woman, revealing that "ic his modor gewearð" ("I have become his mother", 210b); this position of knowledge and emotional control is not inherently a masculine one. While the expression of sorrow is associated with humility and petition, and the woman's role in marriage is portrayed as subordinate, there is no rigid divide between passive, feminine tears and masculine action. Mary both articulates the painfulness of the couple's shared situation and, in the end, resolves it. In so doing, she also reveals her double nature, as both a humble maiden and the Queen of Heaven.

\section{The Relationship with the Audience}

The way Lyric VII elaborates the doubting of Mary episode illustrates how Advent enables its audience to reach a deeper understanding of Christ's incarnation through meditative contemplation. The grieving voice of the betrothed maiden Mary and the authoritative voice of comfort she assumes at the end of the lyric indicate the relationship between the human social world and divine truth, earthly pain and

\footnotetext{
13 Cooper (2011) argues men keep emotion inside in heroic poetry but often weep in Latin narrative sources.
} 
heavenly joy. The question "Hwæt bemurnest pu?" is functional within the interaction between Mary and Joseph but also resonates outwards, inviting the audience to question the nature of Mary's grief, including recognising the difference between deserved and undeserved shame. It might prompt reflection on the need for a salutary, penitential sorrow, like Mary's in intensity if unlike it in cause. At the same time, in the context of a sequence that repeatedly recruits the voice of the audience in words of petition and praise, Lyric VII is a "vignette" that "enhance[s] the relationship between the audience of the poem and the voices invoked in the Advent liturgy" (Bedingfield 2002: 219). The closeness of biblical voices and praying audience has implications for the gendering of emotion.

Lyric VII is the only lyric of Advent to be entirely in the voices of biblical characters. In all the other lyrics, the opening "Eala" is an address in which the audience can prayerfully join. This is true even in Lyric IV: the address to "Eala wifa wynn" ("O joy of women", 71a) effectively comes from all Christians and is only retrospectively assigned to "sunu Solimæ somod his dohtor" ("son of Salem and also its daughter", 91). The opening of the antiphon "O Joseph" is similarly an apostrophe in the voice of the faithful. It is thus especially striking that the opening of the Old English lyric speaks from Mary's perspective. It invites identification with her: not only does her voice take the place occupied by the faithful at prayer in the other lyrics, but her sorrowing stance resembles the petitions from exile found elsewhere in the sequence. Insight into characters' emotions cannot be assumed to generate sympathy for them in Old English poetry, as Mize (2013) and Norcross (2017) have emphasised, noting that the inner states of hostile figures such as Grendel and Satan are explored in detail; in this case, however, the vivid evocation of Mary's sorrow seems likely to enhance a sense of identification which is also prompted by other factors. The culturally salient emphasis on shame also would recruit sympathy. While the audience would be aware of Mary's lack of sin, and in this respect might feel closer to the confused and limited Joseph, their prior knowledge of Christian truth gives them an ironic distance from him. ${ }^{14}$ Mary expresses the pain of human experience, specifically through a vivid, concrete scenario of social shaming, while also offering a model — and a voice-for the audience's faith. The figure of Mary in Lyric VII, therefore, presents in an affectively involving form the promise of her prayer the Magnificat, a prayer used daily in the office of Vespers: the declaration that God "hath exalted the humble" (Luke 1:52). There is a sense of Mary carrying the audience with her from a position of sorrow to one of serene hope and confidence.

To the extent that Lyric VII encourages identification with Mary, it apparently disrupts the gender dynamic that governs Advent. Elsewhere, Mary is viewed from a distance; emphasis is laid on her elevation above all others and the difficulty of comprehending the virgin birth. In Lyric IV Mary says that the "mystery [of the virgin birth] is not revealed to men" ("monnum nis / cuð geryne", 94b-95a); in Lyric IX she is addressed as "pu mæra middan-geardes" ("you glory of the world", 275), Queen, the Lord's bride, and lady of the heavenly host, and compared at great length

\footnotetext{
14 For Joseph's ironized position see Anderson (1971), though Anderson's use of the Greek term "alazon", borrowed from Northrop Frye, is unhelpful insofar as the "alazon" is defined as "normally an object of ridicule" (230). Joseph is not ridiculed, but the audience knows better than he does.
} 
to the locked door in the wall. This last image has been central to arguments that Mary is seen not just from a distance but with a male and eroticized gaze. As Dockray-Miller (2002: 44) puts it, in the imagery of God passing through the doorway and locking it behind him, "Mary's body is reduced to what could be perceived as a grotesque allegory of a giant, locked vagina". For Lara Farina (2001), expanding Lees (1997), the poem exhibits a persistent preoccupation with Mary's body, so often tantalizingly hidden under symbols, and yet a constantly desired object for the gaze: "sippan we moton / an-modlice ealle hyhtan / nu we on pæt bearn foran breostum stariað" ("Then we may all with one mind rejoice when we gaze on the child at your breasts", 339b-41). Farina envisages a male monastic audience who are "poised to penetrate the maternal body" as they read a poem that "promotes but does not in itself satisfy spiritual and erotic desire" (2001: 490 and 491).

Such readings suggest an emphatically male (heterosexual) perspective, and it is not only the arguable undercurrents of eroticism that betray such a perspective. In Lyric IV, the daughters of Jerusalem ("filiae Jerusalem"), who address Mary in the source antiphon "O virgo virginum", become "sunu Solimæ somod his dohtor" (91). While "sunu" alliterates with "Solimæ" and thus serves the verse structure, it also suggests that "daughters" may not have been felt adequate to represent the Christian community. Indeed, Jane Chance (1986: 20-21) interprets the phrase as referring to a son of Jerusalem and his daughter, remarking that the latter remains silent; according to this interpretation, which takes account of "Solimæ" being clearly feminine but "his" neuter or masculine, a male voice has been substituted for the female one in the source. Most translators seem happy to assume that "his" is being used loosely, without strict grammatical concord with the Latin "Solimæ"; thus Bradley gives "son of Jerusalem and you as well, its daughter" (1982: 207), but the female figure still takes second place in this line. The poet's treatment of the daughters of Jerusalem might support a sense that Mary's femaleness narrows her relevance to the audience-that, while a male figure can stand for universal experience, female sex is specific. ${ }^{15}$

While acknowledging that the perspective in Advent is predominantly a male one, Dockray-Miller (2002) uncovers space for a female readership, and the idea that Lyric VII encourages identification with Mary can be used to support her argument. Dockray-Miller discusses how Mary is generally the subject of passive constructions, even in her own speeches, and how her body is occluded and idealised through metaphor both in critical discourse and in the poetic strategies of the lyrics. However, in the image of Mary breast-feeding her child, and in the references to her womb near the end of the poem, the maternal body cannot be reduced to metaphor: Mary's literal, physical motherhood is central to her role in the drama of salvation. Women, including female religious, who were often wives and mothers before they took vows, could have responded to such moments, connecting them to their own

\footnotetext{
15 In the words of Schweickart (1986: 41): "For the male reader, the text serves as the meeting ground of the personal and universal. Whether or not the text approximates the particularities of his own experience, he is invited to validate the equation of maleness with humanity".
} 
bodily experience. One might add that the experience of negotiating with men in pressured social situations affecting the family unit, perhaps through strategic emotional display, could also have been familiar to such women; and that they would be especially well-placed to recognise the active character of Mary's weeping. ${ }^{16}$

However, it is also necessary to account for how identification with Mary and her grief might work across the gender divide. It is striking that it is at the point in Advent when Mary is most vulnerable, when she weeps and is subordinated to Joseph, that she is also least distanced from the audience. Even if the elusive, allusive portrayal of Mary through most of the work is seen as eroticising, it is also the case that Mary is a powerful and authoritative figure, rebuking the children of Salem in Lyric IV and praised as the glory of the world in Lyric IX. In the first part of Lyric VII, in contrast, she is socially marginalised by gossip and, as Joseph's betrothed spouse, she is dependent on his decision regarding their marriage. In Lyric VII, a male audience is offered a female model for the experience of dependency that is elsewhere expressed in passages of sorrowing petition from male or undifferentiated figures, such as the captives in Lyric VI. Caroline Walker Bynum (1982: 144-59), writing about later authors such as Bernard of Clairvaux, Aelred of Rievaulx, and Anselm of Canterbury, comments on how these male writers adopt a feminine position as a position of humility. Weeping and sorrowing in Advent are connected to humility and petition; they are not automatically gendered female, but the female position is a subordinate one. Moreover, womanhood, and specifically motherhood, are central to how the poem discusses human fallenness and distance from God. It is precisely because her motherhood is so unlike that of other women - that, as is repeatedly mentioned, Mary alone gave birth "manes leas ... butan weres frigum" ("without $\sin$... without a man's embraces", 36a and 38b) - that her maternal body is the object of such eroticized/spiritual fascination.

Again, Lyric IV is illuminating. Here the sorrows of mortal existence are explicitly connected with birth and reproduction, and contrasted with the mystery of the virgin birth:

Ne we soðlice swylc ne gefrugnan

in ær-dagum æfre gelimpan

Huru treow in pe
weorðlicu wunade, nu pu wuldres prym
bosme gebære ond no gebrosnad wearð
mægðhad se micla. Swa eal manna bearn
sorgum sawað, swa eft ripað,
cennað to cwealme.
$(78-79,82 b-87 a)$

Truly we have never heard of anything like this happening in former days ... Indeed, a worthy faith has dwelt in you, now you have borne the glory of majesty in your bosom and your great virginity was not defiled. Just as all the children of men sow in sorrows, so they reap again, they procreate for death.

\footnotetext{
${ }^{16}$ For consideration of the circumstances in which women might have had access to a copy of Advent, see Dockray-Miller (2002: 48-49).
} 
The last two lines here recall God's words to Adam and Eve in Genesis 3:16-17, where Adam is condemned to till the earth in the sweat of his brow and Eve to bring forth children in pain. As Burlin points out, the allusion leads into Mary's "assert[ion] of her typological relation to Eve" (1968: 94): "is Euan scyld eal forpynded /... ond gewuldrad is / se heanra had" ("Eve's sin is all done away with ... and the lowlier sex is glorified", 97, 98b-99). For Chance, the focus on the "heanra had" "narrows her regenerative role" (1986: 22). However, it is rather that the lowlier sex, through motherhood, transmits human fleshliness and fallenness. The focus here on Eve's sin is the counterpart of the obsessive interest in Mary's body when trying to comprehend the miracle of Christ's entry into human form. In Lyric VII, a male audience is enabled temporarily to inhabit female lowliness as part of Advent's wider contemplation of how God transforms abjection to glory, further motivating the recurrent plea to Christ to come and save his people.

\section{Conclusion}

The approach offered in this article emphasises how emotional expressions should be interpreted in terms of the establishment of relational stances or positions, and the negotiation of those relationships. The reading of Lyric VII argues that the poet uses emotion discourse to reveal the relationship of Mary and Joseph and their situation, in which they are the targets of shaming gossip. Moreover, the performative character of Mary's speech makes it both a petition and a challenge to Joseph, and her display of grief elicits his response. In Mary's revelation of the angel's message, a very different emotional stance resolves the problems raised in the first two speeches as well as showing the other side of Mary's own identity. The three speeches do not portray a naturalistic human conversation any more than they anatomise character psychology, but they not only meaningfully expound a complex situation, in which Mary is both humble bride and holy mother, but also create a sense of dynamic progression. For the audience, the sorrow of Mary prompts meditation on the difference between social and moral shame, the raising up of the humble, and the promise of salvation to the fallen who call out to God. Female readers might connect the scene to their own experience; male ones are invited to identify with a female position as one element of a prayerful enactment of humility and need for God. It is not the case that sorrow or tears are straightforwardly associated with feminine gender, but sorrow in Advent is generally connected to dependency and petition and thus also aligns in Lyric VII with a wife's subordinate social position. This does not, of course, exhaust the possible meanings of either sorrow or tears across Old English texts.

The profoundest function of Advent may have been intended to be, as Bradley argues, the stimulation of holy tears of compunction, the pricking of the heart to love and fear of God (1982: 203-5; see further Leclercq 1978: 37-39; McEntire 1990). If it achieves this, it does so not through a psychology grounded in individual character, but through one that uses emotion terms to animate, articulate, and prayerfully enact the relationships between holy persons, poetic audiences, and God. 
Funding Open Access funding provided by the IReL Consortium.

\section{Declaration}

Conflict of interest No specific funding was received for the research leading to this article apart from an academic salary and access to institutional resources. There are no ethics considerations or conflicts of interest and the article is not under submission elsewhere.

Open Access This article is licensed under a Creative Commons Attribution 4.0 International License, which permits use, sharing, adaptation, distribution and reproduction in any medium or format, as long as you give appropriate credit to the original author(s) and the source, provide a link to the Creative Commons licence, and indicate if changes were made. The images or other third party material in this article are included in the article's Creative Commons licence, unless indicated otherwise in a credit line to the material. If material is not included in the article's Creative Commons licence and your intended use is not permitted by statutory regulation or exceeds the permitted use, you will need to obtain permission directly from the copyright holder. To view a copy of this licence, visit http://creativecommons.org/licen ses/by/4.0/.

\section{References}

Adair, A. (2011). The unity and authorship of the Old English Advent Lyrics. English Studies, 92(8), 823-848. https://doi.org/10.1080/0013838X.2011.604913.

Anderson, E. R. (1971). Mary's role as eiron in Christ I. JEGP: Journal of English and Germanic Philology, 70(2), 230-240.

Anderson, E. R. (1979). The speech boundaries in Advent Lyric VII. Neophilologus, 63(4), 611-618.

Baker, P. S. (2013). Honour, exchange and violence in Beowulf. Cambridge: Brewer.

Bedingfield, M. B. (2002). The dramatic liturgy of Anglo-Saxon England. Woodbridge: Boydell.

Birnbaum, T. (2015). Naming shame: Translating emotion in Anglo-Saxon Psalter glosses. In A. Jorgensen, F. McCormack \& J. Wilcox (Eds.), Anglo-Saxon emotions: Reading the heart in Old English language, literature and culture (pp. 109-126). Farnham: Ashgate.

Bradley, S. A. J. (1982). Anglo-Saxon poetry. J.M. Dent. Reprinted 1995.

Bremmer, R. H. Jr. (2014). Shame and honour in Anglo-Saxon hagiography, with special reference to Ælfric's Lives of Saints. In L. Lazzari, P. Lendinara \& C. Di Sciacca (Eds.), Hagiography in Anglo-Saxon England: Adopting and adapting saints' lives into Old English prose (c. 950-1150) (pp. 95-120). Barcelona: Fédération internationale des instituts d'études médiévales.

Burlin, R. B. (1968). The Old English Advent: A typological commentary. Yale studies in English 168. Yale University Press.

Campbell, J. J. (1959). The Advent lyrics of the Exeter Book. Princeton: Princeton University Press.

Chance, J. (1986). Woman as hero in Old English literature. Syracuse, NY: Syracuse University Press.

Clark, S. (2018). Compelling God: Theories of prayer in Anglo-Saxon England. Toronto: University of Toronto Press.

Clayton, M. (1990). The cult of the Virgin Mary in Anglo-Saxon England. Cambridge studies in Anglo-Saxon England 2. Cambridge: Cambridge University Press.

Clayton, M. (Ed. and Trans.). (2013). Old English poems of Christ and His saints. Dumbarton Oaks Medieval Library 27. Cambridge, MA: Harvard University Press.

Conner, P. (1993). Anglo-Saxon Exeter: A tenth-century cultural history. Studies in Anglo-Saxon history 4. Woodbridge: Boydell.

Cook, A. S. (1900). The Christ of Cynewulf: A poem in three parts. The Advent, the Ascension, and the Last Judgment. Boston: Ginn/The Athenaeum Press.

Cooper, T.-A. (2011). The shedding of tears in late Anglo-Saxon England. In E. Gertsman (Ed.), Crying in the Middle Ages: Tears of history (pp. 175-192). New York: Routledge.

Cosijn, P. J. (1898). Anglosaxonica IV. Beiträge zur Geschichte der deutschen Sprache und Literatur, $23,109-130$ 
Cowen, A. (2004). Byrstas and bysmeras: The wounds of sin in Wulfstan's Sermo Lupi ad Anglos. In M. Townend (Ed.), Wulfstan, Archbishop of York: The proceedings of the second Alcuin Conference. Studies in the early Middle Ages 10 (pp. 397-411). Turnhout: Brepols.

Dietrich, F. (1853). Cynevulfs Crist. Zeitschrift für deutsches Alterthum, 9, 193-214.

Dockray-Miller, M. (1998). Beowulf's tears of fatherhood. Exemplaria, 10(1), 1-28.

Dockray-Miller, M. (2002). The maternal performance of the Virgin Mary in the Old English "Advent". NWSA Journal, 14(2), 38-55.

Donavin, G. (2012). Scribit mater: Mary and the language arts in the literature of medieval England. Washington, DC: The Catholic University of America Press.

Farina, L. (2001). Before affection: Christ I and the social erotic. Exemplaria, 13(2), 469-496.

Foley, J. M. (1975). Christ 164-213: A structural approach to the speech boundaries in "Advent Lyric VII". Neophilologus, 59, 114-118.

Frantzen, A. J. (2005). Spirituality and devotion in Anglo-Saxon penitentials. Essays in Medieval Studies, 22, 117-128.

Fulk, R. D., Bjork, R. E., \& Niles, J. D. (Eds.). (2008). Klaeber's Beowulf and The Fight at Finnsburg (4th ed.). With a foreword by Helen Damico. Toronto: University of Toronto Press.

Garde, J. N. (1990). Christ I (164-195a): The Mary-Joseph dialogue in medieval Christian perspective. Neophilologus, 74, 122-130.

Greenfield, S. B. (1953). The theme of spiritual exile in Christ I. Philological Quarterly, 32(3), 321-328.

Griffiths, P., \& Scarantino, A. (2009). Emotions in the wild: The situated perspective on emotion. In P. Robbins \& M. Aydede (Eds.), The Cambridge handbook of situated cognition (pp. 437-453). Cambridge: Cambridge University Press.

Harlow, C. G. (1985). The Old English Advent VII and the "Doubting of Mary" tradition. Leeds Studies in English, 16, 101-117.

Hill, J. (1990). "Pæt wæs geomuru ides!” A female stereotype examined. In H. Damico \& A. Hennessey Olsen (Eds.), New readings on women in Old English literature (pp. 235-247). Bloomington: Indiana University Press.

Hill, T. D. (1977). A liturgical source for "Christ I" 164-213 (Advent Lyric VII). Medium AEvum, 46(1), $12-15$.

Hill, T. D. (1986). Literary history and Old English poetry: The case of Christ I, II, III. In P. E. Szarmach with V. Darrow (Eds.), Sources of Anglo-Saxon culture. Studies in Medieval Culture XX (pp. 3-22). Kalamazoo, MI: Medieval Institute Publications.

Isaacs, N. D. (1966). Who says what in “Advent Lyric VII”? (Christ, lines 164-213). Papers on Language and Literature, 2(2), 162-166.

Izdebska, D. (2015). The curious case of TORN: The importance of lexical-semantic-approaches to the study of emotions in Old English. In A. Jorgensen, F. McCormack \& J. Wilcox (Eds.), Anglo-Saxon emotions: Reading the heart in Old English language, literature and culture (pp. 53-74). Farnham: Ashgate.

Jones, C. A. (2013). Performing Christianity: Liturgical and devotional writing. In C. A. Lees (Ed.), The Cambridge history of early medieval English literature (pp. 427-450). Cambridge: Cambridge University Press.

Jorgensen, A. (2013 for 2012). "It shames me to say it": Ælfric and the concept and vocabulary of shame. Anglo-Saxon England, 41, 249-276.

Klinck, A. L. (1979). Female characterization in Old English poetry and the growth of psychological realism: Genesis B and Christ I. Neophilologus, 63(4), 597-610.

Krapp, G. P., \& Dobbie, E. V. K. (1936). The Exeter Book. Anglo-Saxon poetic records 3. New York: Columbia University Press.

Leclercq, J. (1978). The love of learning and the desire for God: A study of monastic culture. Trans. Catherine Misrah. London: SPCK. Originally published as L'Amour des lettres et le désir de Dieu: initiation aux auteurs monastiques du moyen âge. Paris: Éditions du Cerf, 1957.

Lees, C. (1997). Engendering religious desire: Sex, knowledge, and Christian identity in Anglo-Saxon England. Journal of Medieval and Early Modern Studies, 27, 17-45.

Louviot, E. 2016. Direct speech in Beowulf and other Old English narrative poems, Anglo-Saxon studies 30. Cambridge: D.S. Brewer.

Lowrey, B. 2012. Grammaticalisation and the Old English modals. Quaderna, 1. https://quaderna.org/. References by section number. 
McEntire, S. J. (1990). The doctrine of compunction in medieval England: Holy tears. Lewiston: Edwin Mellen Press.

Miller, W. I. (1983). Choosing the avenger: Some aspects of bloodfeud in medieval Iceland and England. Law and History Review, 1(2), 159-204.

Miller, W. I. (1990). Bloodtaking and peacemaking: Feud, law, and society in Saga Iceland. Chicago: University of Chicago Press.

Mills, K. (2015). Emotion and gesture in Hrothgar's farewell to Beowulf. In A. Jorgensen, F. McCormack \& J. Wilcox (Eds.), Anglo-Saxon emotions: Reading the heart in Old English language, literature and culture (pp. 163-192). Farnham: Ashgate.

Mize, B. (2013). Traditional subjectivities: The Old English poetics of mentality. Toronto: University of Toronto Press.

Muir, B. J. (Ed.). (2000). The Exeter anthology of Old English poetry (2nd ed.). 2 vols. Exeter: University of Exeter Press.

Neidorf, L. (2017). Hildeburh's mourning and The Wife's Lament. Studia Neophilologica, 89(2), 197-204.

Norcross, K. R. (2017). Counter-Empathy and elegiac critique in the Old English Christ and Satan. Philological Quarterly, 96(2), 143-170.

Norris, R. (2019). Sad men in Beowulf. In D. C. Remein \& E. Weaver (Eds.), Dating Beowulf: Studies in intimacy. Manchester: Manchester University Press. https://doi.org/10.7765/9781526136442.00019 [unpaginated].

Pope, J. C. (1985). Mary to Joseph, Christ I, 164-67a: A probable scribal error, nu for na. Speculum, 60(4), 903-909.

Rankin, S. (1985). The liturgical background of the Old English Advent lyrics: A reappraisal. In M. Lapidge \& H. Gneuss (Eds.), Learning and literature in Anglo-Saxon England: Studies presented to Peter Clemoes on the occasion of his sixty-fifth birthday (pp. 317-340). Cambridge: Cambridge University Press.

Schweickart, P. P. (1986). Reading ourselves: Towards a feminist theory of reading. In P. P. Schweickart \& E. A. Flynn (Eds.), Gender and reading: Essays on readers, texts, and contexts (pp. 31-62). Baltimore: The Johns Hopkins University Press.

Sebo, E. (2015). Ne sorga: Grief and revenge in Beowulf. In A. Jorgensen, F. McCormack \& J. Wilcox (Eds.), Anglo-Saxon emotions: Reading the heart in Old English language, literature and culture (pp. 177-192). Farnham: Ashgate.

Thorpe, C. (Ed. and Trans.). (1842). Codex Exoniensis: A collection of Anglo-Saxon poetry, from a manuscript in the library of the Dean and Chapter of Exeter. London: William Pickering for the Society of Antiquaries of London.

Toswell, M. J. (2010). Structures of sorrow: The lament psalms in medieval England. In J. Tolmie \& M. J. Toswell (Eds.), Laments for the lost in medieval literature, Medieval texts and cultures of Northern Europe 19 (pp. 21-44). Turnhout: Brepols.

Walker Bynum, C. (1982). Jesus as mother: Studies in the spirituality of the High Middle Ages. Berkeley: University of California Press.

Wilcox, J. (2003). Naked in Old English: The embarrassed and the shamed. In B. C. Withers \& J. Wilcox (Eds.), Naked before God: Uncovering the body in Anglo-Saxon England (pp. 275-309). Morgantown: University of West Virginia Press.

Publisher's Note Springer Nature remains neutral with regard to jurisdictional claims in published maps and institutional affiliations. 